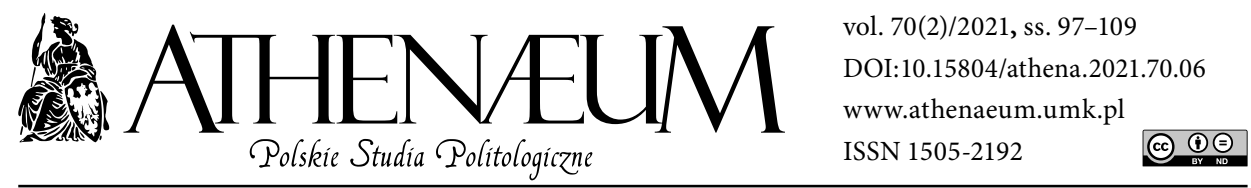

\title{
GENERACJA 50 PLUS WOBEC E-ADMINISTRACJI. PERSPEKTYWA A.D. 2021
}

\author{
GENERATION 50 PLUS VIS À VIS E-ADMINISTRATION: \\ A PERSPECTIVE FOR 2021
}

Beata Stachowiak-Panske* 우

\begin{abstract}
ABSTRAKT
Generacja 50 plus w Polsce w roku 2019 stanowiła $37,5 \%$ społeczeństwa. To grupa zróżnicowana w wielu wymiarach, także w stosunku do e-administracji. W artykule zostaje dokonana analiza postaw respondentów do e-usług w obszarze administracji publicznej oraz przyczyn niekorzystania $\mathrm{z}$ nich. Wyniki badań wskazują na to, że generacja 50 plus rzadziej korzysta $\mathrm{z}$ e-administracji, ale także $\mathrm{z}$ internetu. Sytuacja jednak zmienia się, gdyż wskaźnik niekorzystających $\mathrm{z}$ internetu $\mathrm{w}$ tej grupie sukcesywnie się zmniejsza. Wieloletnie eksploracje wskazują na to, że respondenci przyczyn niekorzystania z e-administracji upatrują przede wszystkim $\mathrm{w}$ poziomie bezpieczeństwa danych przekazywanych online oraz braku umiejętności u obywateli: taki obraz jest niezmienny od wielu lat. W konkluzjach autorka uwzględnia także sytuację związaną z pojawieniem się wirusa SARS-CoV-2, czy
\end{abstract}

ABSTRACT

In 2019, generation 50 plus in Poland constituted $37,5 \%$ of society. It is a group diversified along many dimensions, also with regard to its attitude towards e-administration. This paper analyzes the attitudes of respondents towards e-services in the realm of public administration as well as the reasons why the former are not made use of. The research results demonstrate that generation 50 plus more rarely takes advantage of both e-administration and the Internet at large. However, the situation is changing because the index of the individuals not using the Internet within the scrutinized group gradually decreases. Years-long investigations demonstrate that the respondents rationalize the fact of not taking advantage of e-administration mainly by the level of the security of data transferred online as well as by the lack of relevant skills in citizens. This situation has invariably prevailed for many years

* Uniwersytet Mikołaja Kopernika w Toruniu, Wydział Nauk o Polityce i Bezpieczeństwie. 
jednak obywatele byli i są przygotowani do funkcjonowania urzędów w reżimie sanitarnym?

Słowa kluczowe: e-administracja; pokolenie 50 plus; Polska now. In conclusion, the author also considers the situation connected with the appearance of the virus SARS-CoV-2 and poses the question of whether citizens were and are prepared for public offices operating under a sanitary regime?

Keywords: e-administration; 50 plus generation; Poland

\section{WPROWADZENIE}

Technologie informacyjno-komunikacyjne są składową życia współczesnego człowieka. Znaczna część mieszkańców Polski nie wyobraża sobie funkcjonowania bez dostępu do internetu, usług online, mediów społecznościowych. e-Usługi są oferowane przez podmioty komercyjne, ale i też administrację publiczną. W tej rzeczywistości musi odnaleźć się pokolenie 50 plus, które jako grupa jest bardzo zróżnicowane. Najmłodsi reprezentanci, tzw. silversi, w miarę dobrze radzą sobie z nowymi technologiami, chociaż zdarzają się osoby, sprawnie obsługujące jedynie aplikacje związane $\mathrm{z}$ aktywnością zawodową. Gorzej sytuacja przedstawia się wśród przedstawicieli starszej generacji. To bez wątpienia wyzwanie między innymi dla edukacji nieformalnej. Poziom przygotowania do korzystania z e-administracji generacji 50 plus jest zróżnicowany, co wyraźnie uwidoczniła pandemia koronawirusa.

Stąd tak ważne są badania nad e-administracją. Rozpoznanie, jakie usługi są popularne, a jakie nie, $\mathrm{z}$ jakich powodów obywatele nie chcą z nich korzystać, jakie rozwiązania technologiczne są oczekiwane itp., jest priorytetowe. Szeroka diagnoza pozwoli m.in. na korektę specyfikacji oprogramowania, czyniąc je bardziej przyjaznymi, stworzenie programów edukacyjnych i akcji informacyjnych ${ }^{1}$ skierowanych do różnych grup obywateli.

1 Przykładem w tym miejscu może być pierwsza wersja systemu e-PUAP, która nie cieszyła się popularnością. Sytuacja zmieniła się, gdy umożliwiono logowanie się do systemu za pośrednictwem bankowości elektronicznej oraz wydzielono z systemu profil zaufany. 


\section{GRUPA 50 PLUS W POLSCE}

Pokolenie 50 plus jest zróżnicowane, część to aktywni zawodowo, jednak większość stanowią osoby w wieku emerytalnym. Można rzec, że w grupie tej znajdują się sędziwi mieszkańcy Polski, ale także ich potencjalni opiekunowie. Wykres 1. przedstawia udział poszczególnych grup wiekowych generacji 50 plus, w roku 2019 liczyła ona łącznie 14373404 osób, co stanowiło 37,2\% wszystkich mieszkańców Polski.

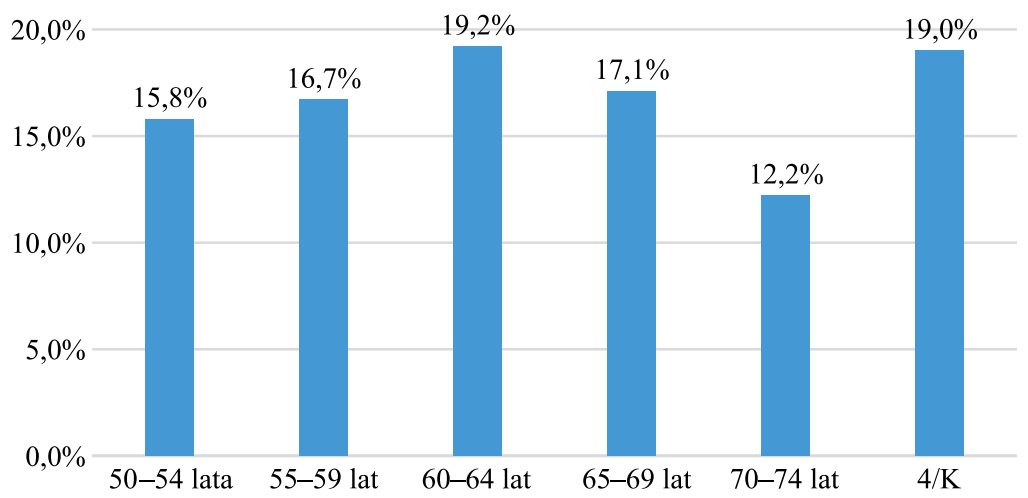

Wykres 1. Grupa 50 plus z podziałem na poszczególne grupy wiekowe w roku 2019

Źródło: Opracowanie własne wg danych GUS.

Grupa 50 plus jest tematem rozważań i badań wielu przedstawicieli nauk społecznych Polsce, dotyczą one różnych płaszczyzn, np. aktywności zawodowej (Wiśniewski, Maksim, 2018), edukacji całożyciowej (Malec-Rowińska, Zakowicz, 2018), seksualności (Wawrzyniak, 2011) czy też poglądów dotyczących zmian społecznych (Stachowiak, 2015). Jeszcze kilka lat temu generację 50 plus otwierało pokolenie wyżu demograficznego z lat powojennych, w chwili obecnej jest inaczej, najmłodszymi są przedstawiciele niżu demograficznego końca lat sześćdziesiątych. Grupa 50 plus jest zróżnicowana nie tylko pod względem wieku, ale także i umiejętności korzystania z ICT, najmłodsi z tej zbiorowości mogli zetknąć się z edukacją informatyczną na studiach czy też w czasie szkoleń zawodowych. Ta zasada nie obejmuje wszystkich. Wiele danych pod kątem korzystania z ICT zawiera Diagnoza społeczna. Ostatnie dane opublikowane w roku 2015 pokazują, że w grupie 65 plus tylko 17,9\% korzystało z internetu, dla porównania w grupie wiekowej 60-64 lata wskaźnik ten wynosił 40,8\%, a 16-24 
lata 97,5\%. Stwierdzenie, że pokolenie 50 plus może być częściowo wykluczone cyfrowo jest w pełni uzasadnione. Widać to także w opracowaniach Głównego Urzędu Statystycznego, które wskazują, że w grupie wiekowej 55-64 lata odsetek regularnie korzystających z internetu wynosi 65,8\%, a 65-74 lata - 40,4\%, dla porównania dla respondentów w wieku 16-24 lata wskaźnik ten wynosi 99,2\%. Grupy te są także zróżnicowane pod kątem umiejętności cyfrowych, dla kategorii 55-64 deklaruje je 25\%, 65-74 lata - 10,1\%, dla porównania osoby w wieku 16-24 90,0\%, a 25-34 lata 75,3\% (GUS 2020). Pewne informacje niosą ze sobą dane z Eurostatu, wskazujące na to, że pozycja Polski w latach 2015-2020 w kategorii używania e-administracji w ostatnich dwunastu miesiącach była nie tylko poniżej średniej, mediany, ale także pierwszego kwartyla. Dotyczy to ogółu społeczeństwa, gdyż dane Eurostatu nie uwzględniają kategorii wiekowych 50 plus. Konkludując, brakuje nadal szeroko sprofilowanych badań dotyczących e-administracji, a ściślej - wykorzystania jej przez jednostkę.

\section{e-ADMINISTRACJA}

Literatura przedmiotu dostarcza wiele określeń pojęcia e-administracja. Najprostsza definicja, zdaniem autorki, opisuje e-administrację jako świadczenie usług administracyjnych za pośrednictwem technologii informacyjno-komunikacyjnych. Rozwiązania technologiczne powinny cechować się m.in.: łatwością użycia, pracą w trybie 24/7, wymiernymi oszczędnościami finansowymi, dostępnością z dowolnego miejsca i z wielu platform oraz szerokiego spektrum urządzeń. Usługi e-administracji są heterogeniczne pod względem zaawansowania, obecnie Komisja Europejska przyjmuje pięciostopniową skalę dojrzałości e-usług, którą przedstawiono na rysunku 1.

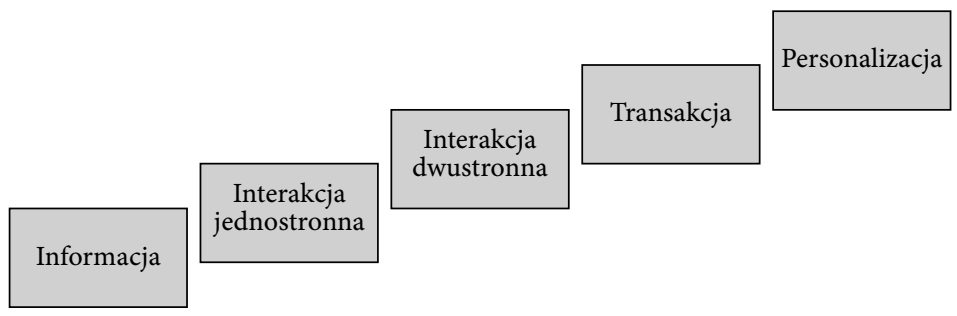

Rysunek 1. Poziomy świadczenia usług $w$ administracji publicznej

Źródło: Opracowanie własne. 
Według tej klasyfikacji najniższym poziomem rozwoju jest informacja, na tym szczeblu wystarczy, by w internecie były prezentowane informacje niezbędne do wszczęcia procedury administracyjnej, nie są konieczne nawet formularze do pobrania. Nieco wyższym stopniem jest interakcja jednostronna, o tym poziomie dojrzałości można powiedzieć wtedy, gdy na publicznie dostępnej stronie internetowej są do pobrania formularze, które petent może pobrać, wydrukować, wypełnić. Natomiast sprawa może być realizowana w sposób tradycyjny, tj. wymagać w kolejnych krokach osobistego stawiennictwa w urzędzie. Trzeci stopień rozwoju nosi nazwę interakcji dwustronnej, aby zakwalifikować procedurę na ten poziom dojrzałości urząd musi udostępniać na stronie internetowej formularze do wypełnienia, zapewniać uwierzytelnianie w systemie teleinformatycznym, umożliwiać złożenie wniosku wraz z załącznikami w formie elektronicznej. Kolejnym, czwartym poziomem dojrzałości jest transakcja, na tym etapie całość usługi jest realizowana na drodze elektronicznej, w szczególności dostarczanie wszystkich dokumentów i doręczeń odbywa się w ten sposób, nie ma jakichkolwiek czynności, które należałoby wykonać w postaci papierowej. Również w przypadku płatności istnieje możliwość jej dokonania w postaci elektronicznej. Ostatnim, piątym stopniem rozwoju jest, jak na razie personalizacja, na tym etapie zakłada się, że formularze w postaci elektronicznej są już częściowo wypełnione danymi posiadanymi przez podmiot publiczny świadczący usługę. Urząd może automatycznie załatwić sprawę, jeśli nie ma konieczności dokonania płatności. Natomiast gdy musi być ona zrealizowana, to wszystkie pola niezbędne do jej realizacji są wypełnione automatycznie.

W założeniu obywatel w tym gąszczu możliwości ma się odnaleźć i efektywnie korzystać $\mathrm{z}$ poszczególnych opcji. $\mathrm{W}$ tym miejscu warto zwrócić uwagę na jeszcze jeden aspekt, aby korzystać z e-administracji, potrzebny jest profil zaufany. Przez wiele lat był on mało popularny, jego założenie było związane $\mathrm{z}$ wizytą $\mathrm{w}$ urzędzie $\mathrm{w}$ celu potwierdzenia tożsamości. A po dwóch latach należało całą procedurę powtórzyć, gdyż profil zaufany ma czasową ważność. Sytuacja zmieniła się, gdy usługę profil zaufany wprowadziło część banków. Ta opcja znacznie ułatwiła korzystanie z profilu zaufanego, lecz okazało się, że część osób z pokolenia 50 plus jest wykluczona - to osoby, którym wydano dowody osobiste o bezterminowej ważności ${ }^{2}$. Obecnie liczba użytkowników wzrasta, niewątpliwie przyczyniła się do tego pandemia, według doniesień prasowych w sierpniu 2019

2 Do 1 marca 2015 roku, wszystkim osobom, które ukończyły 65 lat, wydano dowód osobisty, w którym termin ważności określono jako bezterminowy. 
było 2,5 miliona profili zaufanych, w lutym 2020 już 5 milionów, a w styczniu 2021 blisko 9 milionów. Brakuje danych mówiących o strukturze użytkowników oraz częstotliwości wykorzystywania tego profilu. Zdaniem autorki dla obrazu e-administracji ważne jest to, czy profil założony jest dla jednorazowego działania, czy jest wykorzystywany kilkakrotnie w roku.

\section{METODOLOGIA BADAŃ}

Podstawowym celem badań prowadzonych przez autorkę było poznanie stosunku mieszkańców województwa kujawsko-pomorskiego do e-administracji, w szczególności do takich usług jak BIP czy e-PUAP. Wymienione rozwiązania mają zasięg ogólnokrajowy, stąd każdy mieszkaniec Polski może z nich korzystać. Autorka również podjęła trud wskazania przyczyn niekorzystania $\mathrm{z}$ tych rozwiązań. Badania były prowadzone przez cztery lata: 2016, 2017, 2018 oraz 2019. Badania miały być także przeprowadzone w roku 2020, lecz obostrzenia uniemożliwiły nich przeprowadzenie zgodnie z przyjętą metodologią. Dobór próby był okolicznościowy, łącznie pozyskano 5326 ankiet, które poddano opracowaniu. Zebrano więcej kwestionariuszy, lecz część odrzucono, gdyż np. nie były w całości wypełnione lub zaznaczono zbyt wiele opcji. W tabeli 1.przedstawiono charakterystykę respondentów w poszczególnych latach.

Do badanych skierowano anonimową ankietę zawierającą sześć rozbudowanych pytań i metryczkę, w której respondent określał m.in. swój status zawodowy, częstotliwość korzystania $\mathrm{z}$ internetu, poziom swoich umiejętności czy też wiek. Pytania ankietowe pozwalały na określenie stosunku ankietowanego do e-administracji oraz szczegółowo do wybranych rozwiązań, takich jak Biuletyn Informacji Publicznej, e-Platformy Usług Administracji Publicznej, e-Deklaracji, pobierania formularzy urzędowych, głosowań np. w zakresie budżetu partycypacyjnego itp. Ostatnie pytanie dotyczyło określenia źródeł kontrowersji czy też wątpliwości i niepokoju, które w rezultacie prowadzą do tego, że obywatele nie korzystają z dostępnych e-usług. Badania przeprowadzono wśród mieszkańców województwa kujawsko-pomorskiego.

Artykuł ten skupia się na grupie respondentów określanym mianem 50 plus. Ta część ankietowanych wyróżnia się na tle całej populacji nie tylko wiekiem, ale także samooceną umiejętności w zakresie ICT czy też wskaźnikiem osób

\footnotetext{
3 Ankieta miała postać papierową, aby nie ograniczać respondentów jedynie do internautów.
} 
Tabela 1. Charakterystyka ogółu ankietowanych

\begin{tabular}{|l|c|c|c|c|}
\hline Cecha & $\mathbf{2 0 1 6}$ & $\mathbf{2 0 1 7}$ & $\mathbf{2 0 1 8}$ & $\mathbf{2 0 1 9}$ \\
\hline Średni wiek badanych & 33,9 & 31,4 & 34,2 & 33,3 \\
\hline Mediana wieku badanych & 28 & 25 & 29 & 27 \\
\hline Współczynnik zmienności dla wieku badanych & $44,63 \%$ & $45,8 \%$ & $45,1 \%$ & $45,5 \%$ \\
\hline $\begin{array}{l}\text { Średnia ocena własnych umiejętności w zakresie } \\
\text { użytkowania ICT (w skali 1-5) }\end{array}$ & 3,6 & 3,8 & 3,8 & 3,8 \\
\hline Wskaźnik niekorzystających z internetu w ogóle & $6,8 \%$ & $4,3 \%$ & $5,7 \%$ & $4,2 \%$ \\
\hline Wskaźnik korzystających z internetu codziennie & $56,1 \%$ & $58 \%$ & $53,5 \%$ & $63,4 \%$ \\
\hline
\end{tabular}

Źródło: Badania własne.

korzystających z internetu. Szczegóły zawiera tabela 2. Grupa 50 plus charakteryzuje się także innymi nieco preferencjami, jeżeli chodzi o wybór urządzeń ICT, rzadziej korzystają z urządzeń mobilnych. Podgrupa 50 plus wyróżnia się także w kategorii samoocena umiejętności w zakresie ICT oraz we wskaźnikach osób codziennie korzystających $\mathrm{z}$ internetu.

W pytaniach ankietowych dotyczących stosunku do e-usług w pierwszej części ankiety respondenci mogli wybrać jedną z sześciu możliwości: nie wiem, co to jest (A), wiem, co to jest, ale nie korzystam z takich usług (B), wiem, co to jest, ale nie korzystam i uważam, że takie usługi są zbyteczne (C), wiem, co to jest i korzystam sporadycznie (D), wiem, co to jest i korzystam regularnie (E), wiem, co to jest i korzystam często (F). W opracowaniach na potrzeby tego artykułu stworzono trzy kategorie: nie wiem, co to jest $(A)$, wiem, ale nie korzystam $(B+C)$, wiem i korzystam $(\mathrm{D}+\mathrm{E}+\mathrm{F})$.

Tabela 2. Charakterystyka respondentów w grupie 50 plus

\begin{tabular}{|l|c|c|c|c|}
\hline Cecha & $\mathbf{2 0 1 6}$ & $\mathbf{2 0 1 7}$ & $\mathbf{2 0 1 8}$ & $\mathbf{2 0 1 9}$ \\
\hline Średni wiek badanych & 60,9 & 60,8 & 60,1 & 60,2 \\
\hline Mediana wieku badanych & 60 & 60 & 58 & 58 \\
\hline $\begin{array}{l}\text { Średnia ocena własnych umiejętności w zakresie } \\
\text { użytkowania ICT (w skali 1-5) }\end{array}$ & 2,2 & 2,4 & 2,5 & 2,2 \\
\hline Wskaźnik niekorzystających z internetu w ogóle & $34,4 \%$ & $29,5 \%$ & $33,2 \%$ & $24,6 \%$ \\
\hline Wskaźnik korzystających z internetu codziennie & $18,3 \%$ & $17,9 \%$ & $15,5 \%$ & $14,5 \%$ \\
\hline
\end{tabular}

Źródło: Badania własne. 
W pierwszym rzędzie w ankiecie sformułowano pytanie dotyczące e-administracji, w przypadku grupy 50 plus, korzystanie z tych usług deklaruje niewiele osób, od $16 \%$ do $29 \%$. Wskaźniki dla 50 minus są dwukrotnie wyższe w tym zakresie. Dane zostały przedstawione na wykresie 2 , można nawet zauważyć, że w roku 2019 wskaźnik deklaracji spadł w stosunku do lat poprzednich. Analiza statystyczna danych zastosowana wobec dwóch grup: 50 plus i 50 minus ${ }^{4}$ wskazuje na podstawie testu chi-kwadrat dla dwóch niezależnych próbek, że grupy te różnią się między sobą w sposób statystycznie istotny w zakresie stosunku do e-administracji. Wskazują na to odpowiednio wartości chi-kwadrat, które wynoszą dla roku 2016 - 164,88; 2017 63,18; 2018 - 84,91; 2019 - 34,30 przy wartości krytycznej 5,991 dla poziomu istotności 0,05 stosowanego standardowo w naukach społecznych. Analiza statystyczna potwierdziła także, że w ciągu czterech lat zmienił się stosunek respondentów do e-administracji w sposób statystycznie istotny dla grupy 50 plus, jak i 50 minus. Dowodzą tego wartości chi-kwadrat dla czterech niezależnych próbek, w przypadku 50 plus chi-kwadrat 14,93, a 50 minus 14,01 przy wartości krytycznej 12,592.
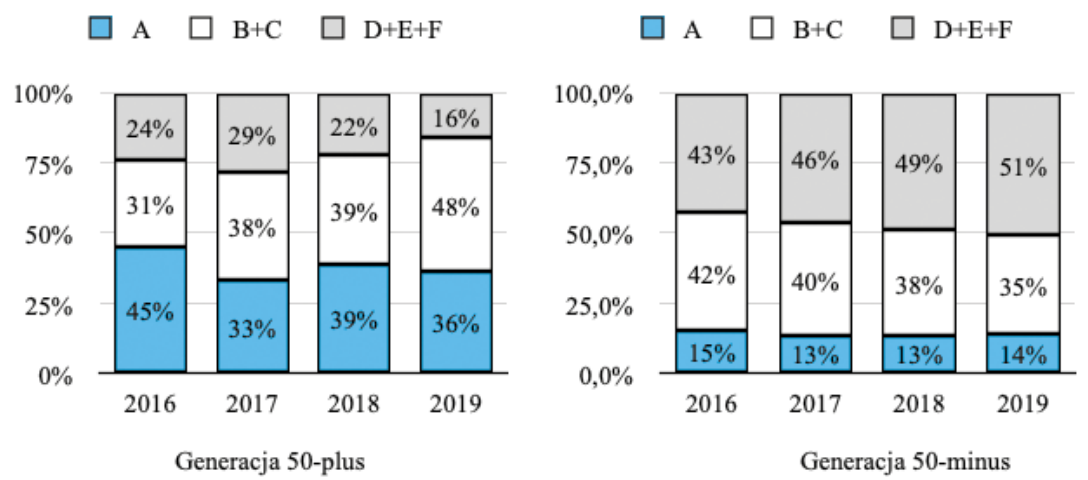

Wykres 2. Stosunek respondentów do e-administracji w latach 2016-2019 Źródło: Badania własne.

Kolejną usługą, do której mają dostęp wszyscy obywatele, jest Biuletyn Informacji Publicznej, wprowadzany w 2001 roku ustawą o dostępie do informacji publicznych. Wiele organów i jednostek jest zobowiązanych do jego prowadzenia, czy jednak ta usługa jest popularna? Okazało się jednak, że tak usługa jeszcze

4 Te dwie grupy tworzą dwa rozłączne zbiory. 
jest mniej znana niż szeroko pojęta e-administracja, chociaż stanowi jej element składowy. W grupie 50 plus ponad 40\% deklaruje, że nie zna tej usługi, szczegóły przedstawia wykres 3., poziom nieznających utrzymuje się w grupie właściwie na tym samym poziomie, w roku 2019 następuje pewne zaburzenie: wzrasta wskaźnik znających, ale niekorzystających i nagle spada odsetek korzystających. Dla porównania w grupie 50 minus ten wskaźnik jest na poziomie $13 \%-15 \%$. Analiza statystyczna danych zastosowana wobec dwóch grup: 50 plus i 50 minus wskazuje na podstawie testu chi-kwadrat dla dwóch niezależnych próbek, że grupy te różnią się między sobą w sposób statystycznie istotny w zakresie stosunku do BIPu. Wskazują na to odpowiednio wartości chi-kwadrat, które wynoszą dla roku 2016 - 67,88; 2017 - 66,59; 2018 - 85,84; 2019 - 23,47 przy wartości krytycznej 5,991 dla poziomu istotności 0,05. Analiza statystyczna potwierdziła także, że w ciągu czterech lat zmienił się stosunek respondentów do BIPu w sposób statystycznie istotny, zarówno grupy 50 plus, jak i 50 minus. Dowodzą tego wartości chi-kwadrat dla czterech niezależnych próbek, w przypadku 50 plus 14,37, a 50 minus 89,35, przy wartości krytycznej 12,592.
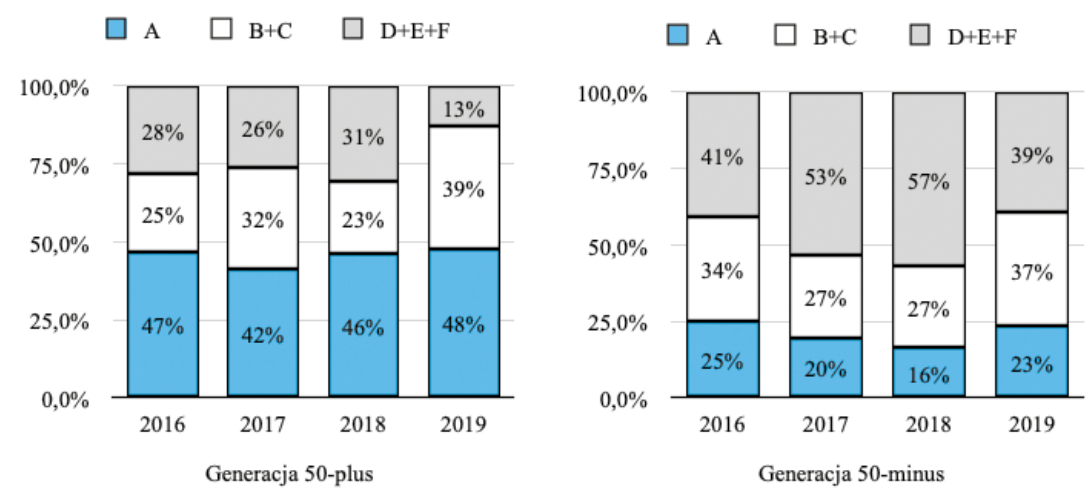

Wykres 3. Stosunek respondentów do BIPu w latach 2016-2019

Źródło: Badania własne.

Inną usługą, która znalazła się w kręgu zainteresowań autorki, był e-PUAP, czyli elektroniczna platforma usług administracji publicznej. Okazała się ona najmniej znanym rozwiązaniem. O tyle to jest zaskakujące, że e-PUAP to przepustka czy klucz do wielu innych usług. W przypadku pokolenia 50 plus około $60 \%$ respondentów deklaruje, że nie zna tej usługi, dla grupy 50 minus ten parametr jest dwukrotnie mniejszy. Szczegóły przedstawia wykres 4 . Analiza statystyczna 
danych zastosowana wobec dwóch grup: 50 plus i 50 minus wskazuje na podstawie testu chi-kwadrat dla dwóch niezależnych próbek, że grupy te różnią się między sobą w sposób statystycznie istotny w zakresie stosunku do e-PUAPu. Wskazują na to odpowiednio wartości chi-kwadrat, które wynoszą dla roku 2016 - 68,26; 2017-33,87; 2018 - 102,54; 2019 - 18,38 przy wartości krytycznej 5,991 dla poziomu istotności 0,05. Analiza statystyczna wskazała także na to, że w ciągu czterech lat zmienił się stosunek respondentów do e-PUAPu w sposób statystycznie istotny, jedynie dla grupy 50 minus, lecz nie ma takiej zmiany dla 50 plus. Dowodzą tego wartości chi-kwadrat dla czterech niezależnych próbek, w przypadku 50 minus chi-kwadrat wynosi 129,54, a 50 plus jedynie 9,81 przy wartości krytycznej 12,592.
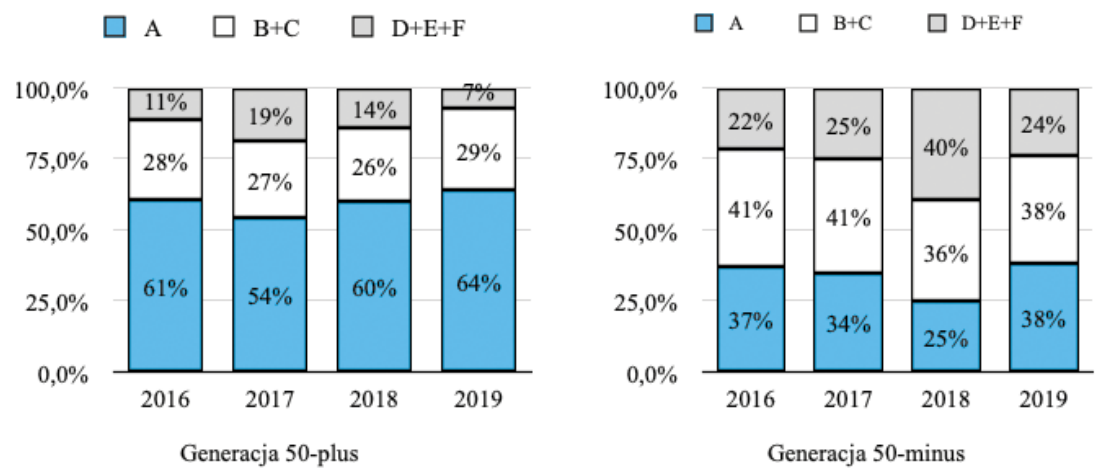

Wykres 4. Stosunek respondentów do e-PUAPu w latach 2016-2019

Źródło: Badania własne.

Wyniki nie napawają optymizmem, tym bardziej gdy rozpatruje się jej w kontekście wydatków przeznaczonych na informatyzację sektora administracji publicznej i samorządowej. A także zmian w funkcjonowaniu urzędów w dobie koronowirusa. Cześć generacji 50 plus nie zna rozwiązań z zakresu e-administracji, czy to jednak oznacza, że nie interesuje się nowymi rozwiązaniami technologicznymi? Temu poglądowi przeczy stosunek respondentów do zakupów online. Na wykresie 5. zostały przedstawione wyniki badań, różnica jest duża. Obie grupy deklarują korzystanie i znajomość z zakupów online, częstsze niż w przypadku usług z zakresu e-administracji. Nie można wykluczyć, że korzystają z tych form, bo są znane i są bardziej przydatne w życiu codziennym. Podobnie jak w przypadku usług e-administracji, także w przypadku zakupów 
online obie grupy różnią się między sobą w sposób statystycznie istotny. Analiza statystyczna danych zastosowana wobec dwóch grup: 50 plus i 50 minus wskazuje na podstawie testu chi-kwadrat dla dwóch niezależnych próbek, że grupy te różnią się między sobą w sposób statystyczny. Wskazują na to odpowiednio wartości chi-kwadrat, które wynoszą dla roku 2016 - 541,63; 2017 - 342,61; 2018 - 383,23; 2019 - 23,47 przy wartości krytycznej 5,991 dla poziomu istotności 0,05 . Analiza statystyczna potwierdziła także, że w ciągu czterech lat zmienił się stosunek respondentów do zakupów internetowych w sposób statystycznie istotny jedynie dla 50 minus. Dowodzą tego wartości chi-kwadrat dla czterech niezależnych próbek, w przypadku 50 plus 6,59, a 50 minus 20,70, przy wartości krytycznej 12,592.

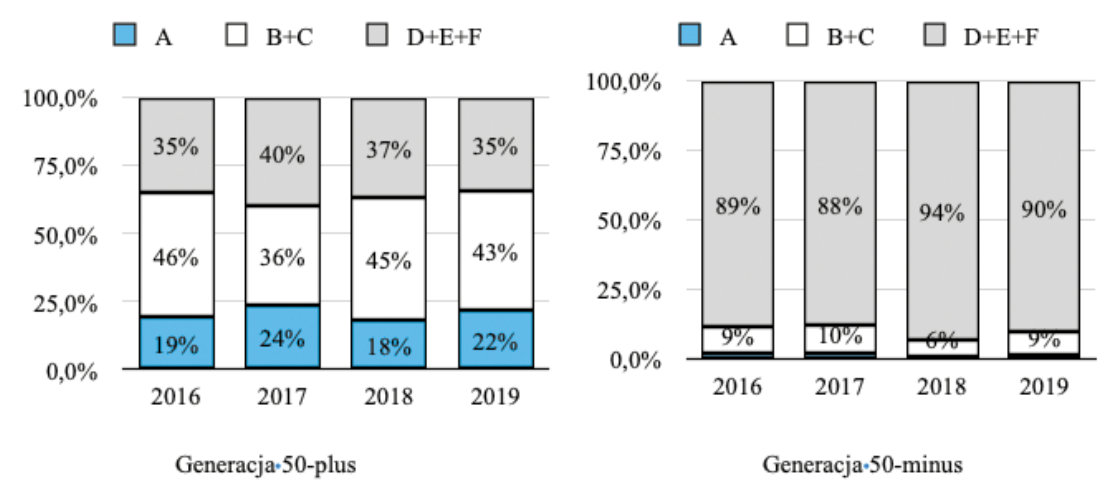

Wykres 5. Stosunek respondentów do zakupów online w latach 2016-2019 Źródło: Badania własne.

Autorka także zwróciła się do respondentów z pytaniem o przyczyny niekorzystania z e-administracji. Przez cztery lata badań właściwie nie zmieniały się, układ najczęściej podawanych wariantów był stały, szczegóły zawierają tabele 3. i 4. Uwagę przykuwa fakt, że respondenci największy nacisk kładą na kwestie związane $\mathrm{z}$ bezpieczeństwem aplikacji oraz brakiem umiejętności u obywateli. Oznacza to, że respondenci z generacji 50 plus diagnozują braki w umiejętnościach i kompetencji u siebie, jak i u innych, w szczególności w zakresie bezpiecznego korzystania $\mathrm{z}$ tych aplikacji. W pierwszych dwóch latach badań respondenci z tej grupy wiekowej zwracali także uwagę na to, że brakuje akcji informacyjnych o dostępnych dla obywateli e-usługach. Wskazania respondentów z obu grup pokrywają się w 58\%, jeżeli tabele potraktowałoby się jako macierze. 
Tabela 3. Przyczyny niekorzystania z e-administracji przez pokolenie 50 plus

\begin{tabular}{|c|c|c|c|c|}
\hline & Rok 2016 & Rok 2017 & Rok 2018 & Rok 2019 \\
\hline 1. & $\begin{array}{c}\text { Poziom bezpieczeństwa } \\
\text { danych przekazywa- } \\
\text { nych online } 41,7 \%\end{array}$ & $\begin{array}{c}\text { Poziom bezpieczeństwa } \\
\text { danych przekazywa- } \\
\text { nych online } 42,0 \% \%\end{array}$ & $\begin{array}{l}\text { Brak umiejętności } \\
\text { u obywateli } 42,5 \%\end{array}$ & $\begin{array}{c}\text { Poziom bezpieczeństwa } \\
\text { danych przekazywa- } \\
\text { nych online } 42,0 \%\end{array}$ \\
\hline 2. & $\begin{array}{l}\text { Brak umiejętności } \\
\text { u obywateli } 39,2 \%\end{array}$ & $\begin{array}{l}\text { Brak umiejętności } \\
\text { u obywateli } 41,5 \%\end{array}$ & $\begin{array}{c}\text { Poziom bezpieczeństwa } \\
\text { danych przekazywa- } \\
\text { nych online } 40,4 \%\end{array}$ & $\begin{array}{l}\text { Brak umiejętności } \\
\text { u obywateli } 37,7 \%\end{array}$ \\
\hline 3. & $\begin{array}{c}\text { Brak akcji informa- } \\
\text { cyjnych dla obywa- } \\
\text { teli o możliwościach } \\
\text { korzystania z e-usług } \\
22,3 \%\end{array}$ & $\begin{array}{c}\text { Brak akcji informa- } \\
\text { cyjnych dla obywa- } \\
\text { teli o możliwościach } \\
\text { korzystania z e-usług } \\
21,0 \% \%\end{array}$ & $\begin{array}{c}\text { Stopień skomplikowa- } \\
\text { nia usług świadczonych } \\
\text { drogą elektroniczną } \\
17,6 \%\end{array}$ & $\begin{array}{l}\text { Niski poziom } \\
\text { przyjazności systemów } \\
\text { informatycznych dla } \\
\text { użytkowników 23,2\% }\end{array}$ \\
\hline
\end{tabular}

Źródło: Badania własne.

Tabela 4. Przyczyny niekorzystania z e-administracji przez respondentów 50 minus

\begin{tabular}{|c|c|c|c|c|}
\hline Rok 2016 & Rok 2017 & Rok 2018 & Rok 2019 \\
\hline 1. & $\begin{array}{c}\text { Poziom bezpieczeństwa } \\
\text { danych przekazywa- } \\
\text { nych online } \\
44,3 \% \%\end{array}$ & $\begin{array}{c}\text { Poziom bezpieczeństwa } \\
\text { danych przekazywa- } \\
\text { nych online } \\
48,9 \% \%\end{array}$ & $\begin{array}{c}\text { Poziom bezpieczeństwa } \\
\text { danych przekazywa- } \\
\text { nych online } \\
44,7 \% \%\end{array}$ & $\begin{array}{c}\text { Poziom bezpieczeństwa } \\
\text { danych przekazywa- } \\
\text { nych online } \\
50,4 \%\end{array}$ \\
\hline 2. & $\begin{array}{c}\text { Brak umiejętności } \\
\text { u obywateli 28,3\% }\end{array}$ & $\begin{array}{c}\text { Brak umiejętności } \\
\text { u obywateli 30,5\% }\end{array}$ & $\begin{array}{c}\text { Brak umiejętności } \\
\text { u obywateli 27,1\% }\end{array}$ & $\begin{array}{c}\text { Brak umiejętności } \\
\text { u obywateli } 27,5 \%\end{array}$ \\
\hline \multirow{2}{*}{3.} & $\begin{array}{c}\text { Brak akcji informa- } \\
\text { cyjnych dla obywa- } \\
\text { teli o możliwościach } \\
\text { korzystania z e-usług } \\
20,9 \%\end{array}$ & Brak szkoleń dla & $\begin{array}{c}\text { Brak akcji informa- } \\
\text { cyjnych dla obywa- } \\
\text { teli o możliwościach } \\
\text { korzystania z e-usług } \\
20,4 \%\end{array}$ & $\begin{array}{c}\text { Nieprzystosowanie } \\
\text { polskich urzędów do } \\
\text { rozwiązań informa- } \\
\text { tycznych 23,1\% }\end{array}$ \\
\hline
\end{tabular}

Źródło: Badania własne.

\section{KONKLUZJE}

Badania autorki były przeprowadzane przez cztery lata, to długi okres, szczególnie gdy jest rozpatrywany w kontekście rozwoju technologii. W ciągu tych czterech lat nastąpił rozwój w Polsce także e-administracji. Lecz zmiana ta nie była w pełni skorelowana $\mathrm{z}$ reorientacją postaw respondentów. Wydaje się, o czym autorka jest w pełni przekonana, że transformacja na płaszczyźnie petent - e-administracja 
wymaga nie tylko dostarczania wciąż nowych rozwiązań technologicznych, lecz sprawnie prowadzonych akcji informacyjnych i edukacyjnych skierowanych do obywateli należących przecież do różnych grup wiekowych. Każda z generacji wymaga innego podejścia, nie tylko pod względem zakresu treści, ale także sposobu ich przekazywania. Pokolenie 50 minus ma inne doświadczenia związane z ICT niż grupa 50 plus, obie te zbiorowości są zróżnicowane wewnętrznie. Przygotowanie społeczeństwa do korzystania z e-administracji jest kluczowe, gdyż zapobiegnie wykluczeniu społecznemu niektórych grup. Badania także wskazują, na jaki element należy kłaść nacisk w akcjach informacyjnych - jest nim bezpieczeństwo danych. Brak zaufania respondentów do poziomu cyberbezpieczeństwa w e-administracji jest wyraźny, kwestia ta będzie stawała się jeszcze ważniejsza w dobie upowszechniania aplikacji mobilnych. Zwiększenie zaufania obywateli do rozwiązań e-administracji nie może odbywać się tylko w obszarze szkoleń, akcji informacyjnych. Powinno to także znaleźć odbicie w strategiach cyberbezpieczeństwa kraju, działaniach instytucji centralnych, a także rozwoju informatyki śledczej i przede wszystkim podejmowaniu działań prewencyjnych.

\section{BIBLIOGRAFIA:}

Czapiński, J., Panek, T. (2015). Diagnoza społeczna. Warszawa.

Mendyk, I. (2016). Uwarunkowanie doskonalenia kompetencji pracowników 50+. Wyniki badań. Zeszyty Naukowe. Organizacja i Zarzadzanie Politechniki Śląskiej, 97,213-223.

Malec-Rawińska, M., Zakowicz I. (2018). Renesans czy zmierzch idei uniwersytetów trzeciego wieku? Refleksje i wnioski z realizacji projektu „UTW: Uczyć - Tworzyć - Wspierać", Rocznik Andragogiczny, 141-156.

Społeczeństwo informacyjne w Polsce. (2019). Wyniki badań statystycznych z lat 2015-2019. Warszawa.

Stachowiak, B. (2015). Zagrożenia jednostki w życiu osobistym i rodzinnym w społeczeństwie informacyjnym w opinii generacji 50+. Rocznik Andragogiczny, 181-196.

Wawrzyniak, J. (2011). Seksualność osób 50 plus. Wybrane konteksty zjawiska, Edukacja Dorostych, 1, 65-75.

Wiśniewski, Z., Maksim, M. (2018). Sytuacja i aktywizacja zawodowa bezrobotnych 50 plus - doświadczenia niemieckie. Problemy Polityki Społecznej, 23(XXIII), Issue 3, 23-36. 